Nalar: Jurnal Peradaban dan Pemikiran Islam

Vol. 2, No. 2, Desember 2018

\title{
Statemen Sari Roti Pasca 212 dalam Perspektif Filsafat bahasa Biasa John Langshaw Austin
}

\author{
Syairil Fadli \\ Institut Agama Islam Negeri Palangka Raya, Indonesia \\ ayatullah.filsafat@gmail.com
}

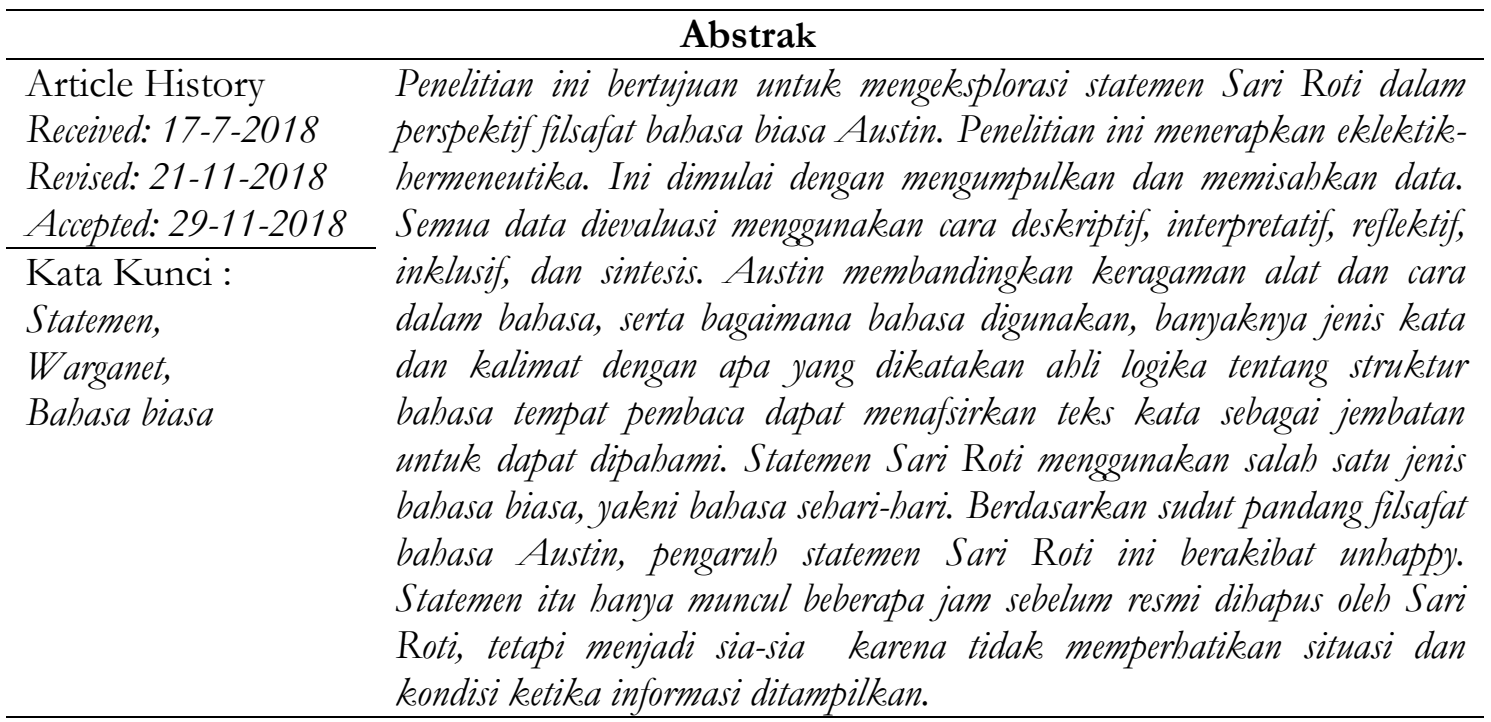

\section{Pendahuluan}

Media massa, baik cetak maupun elektronik selalu disibukkan oleh berbagai berita yang berkaitan dengan persoalan sosial, politik, keagamaan, dan respon yang muncul akibat pemberitaan tersebut. Respon muncul karena kata-kata yang dituangkan dianggap tidak pas sehingga menjadi multitafsir. Salah satu pemberitaan tersebut berkaitan dengan penistaan agama yang dilontarkan oleh Basuki Tjahaya Purnama, atau lebih dikenal dengan panggilan Ahok, yang ujung-ujungnya mengakibatkan munculnya gelombang aksi di berbagai tempat di Indonesia, termasuk berbagai akibat lain karena aksi tersebut.

Keadaan yang dipaparkan di atas pada dasarnya berkaitan dengan bahasa yang dipergunakan oleh seseorang yang direspon oleh orang lain. Bahasa ini melibatkan kata-kata sebagai bentuk pemikiran yang muncul dari seseorang. Meskipun, kata sebagai ungkapan bahasa tidak dapat mengubah alam benda-benda, tidak dapat mengubah kehendak Tuhan, akan tetapi bukan berarti kata tidak punya kekuatan sama sekali (Kaelan, 1988:24). Dengan kata lain, fungsi magis kata yang mulai buram digantikan oleh fungsi semantis. Dari sinilah manusia sadar terdapat hubungan antara bahasa melalui kata dengan realitas dari sudut berbeda. Sebagai makhluk yang senantiasa bergerak dan mengalami perubahan, tidak sedikit hubungan antar sesama menimbulkan ketidakselarasan. Oleh karena itu diperlukan suatu komunikasi, salah satunya adalah melalui bahasa (Mustansyir, 1995:46).

Selain bahasa lisan, manusia juga mengenal bahasa tulis. Bahasa tulis digunakan sebagai tapal batas antara zaman prasejarah dan sejarah antara satu komunitas dengan komunitas lain. Dewasa ini, bahasa tulis lebih penting dibandingkan dengan bahasa lisan. Meskipun kedua bahasa ini berfungsi mengkomunikasikan pengalaman, kegembiraan, kesedihan, pengetahuan, dan lain sebagainya. Bahasa tulis lebih sistematis dan dapat dibaca serta dianalisa oleh orang lain. Bahasa tulis berkembang sedemikian rupa mulai dari bentuk yang paling sederhana sampai dengan yang canggih, seperti surat kabar, majalah, dan internet. 
Nalar: Jurnal Peradaban dan Pemikiran Islam

Vol. 2, No. 2, Desember 2018

Pemakaian internet yang marak merambah ke telepon pintar (smartphone) membuat orang yang berjejaring di dalamnya berkesempatan menjadi hakim dari semua persoalan. Peradaban manusia kemudian secara pelan mulai beralih ke dunia virtual yang tidak terbayangkan sebelumnya. Kegelisahan purba umat manusia yang ingin mencari jawaban dari kehadirannya di dunia ini, terjawab dengan kehadiran media sosial. Pada tahap selanjutnya muncul tabiat dasar manusia yang selama ribuan tahun terpendam begitu dalam. Muncul segolongan manusia baru yang gemar mematut diri dalam semua akun media sosial yang mereka miliki. Seolah di dalam akun itulah hidupnya menemukan ruang untuk mengada.

Demikian pula apa yang terjadi pada Aksi Super Damai 212. Aksi ini memperlihatkan pemandangan yang luar biasa bagi banyak orang. Foto-foto suasana menjelang, saat, hingga usai acara dengan mudah ditemui di berbagai media. Viral juga mengenai foto yang menggambarkan penyedian roti gratis merek Sari Roti yang diperuntukkan bagi peserta aksi, meskipun tidak lama kemudian muncul klarifikasi bahwa pembagian roti gratis itu hanya inisiatif para dermawan, bukan perusahaan pemilik Sari Roti. Lagi-lagi bantahan ini juga viral yang berujung pada pemboikotan terhadap Sari Roti.

Dengan demikian, dalam konteks tersebut Wittgenstein menyebutkan bukan hanya pembuat tulisan dan laman yang perlu memperhatikan aturan tata permainan berbahasa (The Language-Games). Wittgenstein (dalam Bertens, 2002:52), mengibaratkan bahasa sebagai permainan karena dalam suatu permainan terdapat berbagai macam aturan, termasuk norma yang dipakai untuk menentukan pemenang, tidak mencampur antara fakta dan opini agar tidak menimbulkan kebingungan, tetapi juga, dalam hal ini warganet harus pintar dan bijaksana dalam memahami dan mengartikan kata atau kalimat yang tersaji. Hal ini perlu dilakukan dengan harapan bahasa yang semula dianggap biasa menurut penutur menjadi tidak biasa (menurut pembaca), bahkan disalahartikan. Komunikasi yang semestinya terjalin menjadi berantakan.

Pengumuman Sari Roti tidak hanya memberikan informasi, tetapi juga mempunyai sikap sebagaimana media yang lain. Sikap itu berupa arena perjuangan kepentingan, baik politik, budaya, maupun personal. Sikap ini juga menimbulkan polarisasi di kalangan pembaca atau netizen yang berangkat dari individu ke kelompok. Sikap kebencian misalnya, bisa saja muncul dari ekpresi personal kelompok yang memicu konflik horizontal, terlebih lagi ia cepat menyebar karena orang Indonesia yang paternalistik senang berkelompok.

Relevan dengan hal seperti di atas, isi pengumuman Sari Roti Pasca Aksi Super Damai 212 layak dicermati menurut kajian bahasa, termasuk apa yang dikemukakan oleh John Langshaw Austin (selanjutnya Austin). Austin banyak memunculkan gagasan baru yang berkaitan dengan bahasa sehari-hari, terutama mengenai jenis ucapan (utterances) dan tindakan bahasa (speech acts) dalam pergaulan sehari-hari. Austin secara seksama membedakan beberapa macam tindakan bahasa dan jenis ucapan dengan berbagai kriteria dan implikasinya masing-masing. Belum lagi akibat yang dimunculkan oleh pembuat tuturan dengan berbagai konsekuensi yang seharusnya dilaksanakan (Mustansyir, 1995:103).

Austin adalah orang yang mengembangkan pemikiran filsafat bahasa biasa Wittgenstein dengan lebih menekankan pada situasi konkret tempat bahasa itu digunakan (Kaelan, 2006:5). Menurut Bertens (2002:60), dibanding dengan para filsuf lain, Austin adalah orang yang paling bersemangat dalam menyelidiki bahasa biasa.

Sumber penelitian disandarkan secara langsung dengan menelaah isi pengumuman Sari Roti dan menyimak karya Austin dan tulisan lain yang ada relevansi dengan metode pembahasan yang diterapkan. Sebagaimana dirumuskan Bakker (1986:19), filsafat tidak menerima kewibawaan di luar filsafat yang mau membahasnya dan tidak akan menerima kompetensi lahiriah untuk menilai metodenya. Oleh karena itu, penelitian ini terfokus 
Nalar: Jurnal Peradaban dan Pemikiran Islam

Vol. 2, No. 2, Desember 2018

untuk mengkaji dua aspek. Pertama, kelayakan bahasa pengumuman yang digunakan oleh Sari Roti dalam perspektif John. L. Austin. Kedua, dampak yang ditimbulkan oleh pengumuman Sari Roti dalam perspektif filsafat bahasa biasa John L. Austin.

Temuan dalam penelitian ini dianalisa menggunakan metode hermeneutika-eklektis. Dalam metode ini semua sistem dapat diambil dan digunakan karena manusia mempunyai sifat eklektis (Sudarto, 1996:93). Subjek dalam penelitian ini adalah epistemologi sedangkan metodenya adalah deskriptik, interpretasi, reflektif, dan sintesis. Masing-masing metode memiliki tolak ukur tersendiri guna membuktikan kebenaran temuan. Masing-masing metode yang digunakan peneliti ini saling melengkapi dalam membentuk isi penelitian secara utuh dan menyeluruh.

Deskriptif merupakan langkah awal dalam melakukan penelitian sebagai proses penyatuan data dan merangkum apa adanya dengan susunan sederhana tanpa bermaksud mengambil kesimpulan. Interpretasi berarti menyelami untuk menangkap nuansa yang dimaksud filsuf secara khas, dalam hal ini yang berkaitan dengan bahasa. Reflektif digunakan karena peneliti bukan penonton yang tidak terlibat sama sekali. Peneliti berefleksi pada implikasi metode, bias, dan disiplin ilmu yang telah dimiliki. Tentu saja dengan cara refleksi diri yang kritis. Terakhir, sintesis diarahkan untuk menarik beberapa simpulan sebagai kesatuan pendapat yang lengkap.

\section{Hasil dan Pembahasan}

Perkembangan teknologi informasi dan sejenisnya yang mempunyai dua sisi. Di satu, teknologi informasi, terlebih dengan kemunculan telepon pintar yang memuat media sosial seperti facebook, twitter, dan instagram membawa berkah dan kemudahan bagi manusia untuk berkomunikasi satu sama lain. Di sisi lain, kehadirannya menimbulkan kegelisahan. Orang begitu gampang percaya terhadap berita yang tersebar sedemikian cepat, tanpa kejelasan sumbernya. Dunia maya yang diwakili oleh media sosial menjadi semacam saluran pembuangan karena terdapat muatan kebencian, fitnah, provokasi, hoax, sikap intoleran, semuanya hampir tidak tersaring untuk cek dan ricek sumbernya. Masyarakat seakan terhempas oleh gelombang modernitas yang begitu dahsyat.

Internet sebagai salah satu bentuk kegunaan teknologi digital telah membebaskan manusia dari kungkungan ruang dan waktu. Manusia dapat melakukan berbagai aktivitas kapan dan dimanapun sepanjang terdapat koneksi internet. Internet sebagai hasil "ciptaan" manusia, justru menjadikan manusia seperti makhluk gaib yang dapat berada di mana-mana, meski tidak ke mana-mana. Menurut Priyatna (2017:7), manusia memang banyak mengambil manfaat dari keberadaan teknologi digital ini, terutama yang berkaitan dengan efisiensi dan produktivitas, akan tetapi karena kedahsyatannya sebagai alat kendali jarak jauh, teknologi ini dapat menjadi sarana represi oleh pihak yang punya kekuatan dan kekuasaan.

Pandangan di atas, dapat ditemukan ketika muncul beragam aksi dan reaksi terhadap suatu peristiwa, apa pun alasannya. Kisruh ucapan Basuki Tjahaya Purnama di Kepulauan Seribu berkaitan dengan surat Al-Maidah Ayat 51 misalnya, telah membuat kehebohan jagat maya dan nyata di seantero nusantara dan mancanegara. Gelombang aksi yang muncul, terutama aksi 212 sebagai salah satu bentuk protes terhadap pernyataan Basuki Tjahaja Purnama tersebut menyebabkan berbagai persoalan mengemuka, termasuk bagaimana publik menyikapi kehadiran Sari Roti.

Pada aksi yang dilakukan bertanggal 2 Desember 2016, terdapat pedagang Sari Roti yang membagikan barang dagangnya secara gratis untuk para peserta aksi solidaritas. Beberapa foto pedagang Sari Roti pun sempat menjadi viral setelah aksi bagi-bagi roti gratis ini. Pihak Sari Roti melihat pembagian produknya secara gratis dalam sudut pandang yang 
Nalar: Jurnal Peradaban dan Pemikiran Islam

Vol. 2, No. 2, Desember 2018

berbeda. Sebagai upaya untuk tidak dikaitkan dengan aksi politik, Produsen Sari Roti, PT Nippon Indosari Corpindo Tbk. angkat bicara tentang pembagian dagangannya secara gratis yang sempat menjadi viral. Melalui pengumuman resmi yang diluncurkan pada website Sari Roti, disebutkan bahwa kejadian pembagian roit tersebut adalah diluar dari kebijakan dan tanpa sepengetahuan perusahaan. Adapun bunyi pengumuman Sari Roti secara utuh sebagaimana dikutip dari laman Tribunnews (2016) berikut ini:

"Sehubungan dengan beredarnya informasi mengenai adanya pembagian produk Sari Roti secara gratis oleh penjual roti keliling (hawker tricycle) para aksi Super Damai 212, dengan ini kami sampaikan. 1) PT. Nippon Indosari Corpindo Tbk, selaku produsen produk Sari Roti memberikan apresiasi sebesar-besarnya atas terlaksananya Aksi Super Damai 212 yang berjalan dengan lancar dan tertib pada tanggal 2 Desember 2016.2) PT. Nippon Indosari Corpindo Tbk senantiasa berkomitmen menjaga nasionalisme, keutuhan Negara Kesatuan Republik Indonesia (NKRI) dan Bhineka Tunggal Ika dengan senantiasa berusaha untuk menjadi perusahaan kebanggaan Indonesia. 3) Dengan tidak mengurangi apresiasi kami atas Aksi Super Damai 212, dengan ini kami sampaikan bahwa PT. Nippon Indosari Corpindo Tbk tidak terlibat dalam semua kegiatan politik. Kemunculan informasi mengenai pembagian produk Sari Roti secara gratis oleh penjual roti keliling (bawker tricycle), merupakan kejadian yang berada di luar kebijakan dan tanpa seizin PT. Nippon Indosari Corpindo Tbk. Sehubungan dengan hal tersebut, dengan PT. Nippon Indosari Corpindo Tbk menyampaikan bahwa: 1) Produk Sari Roti tersebut adalah produk yang dibeli oleh seorang konsumen melalui salah satu agen yang berlokasi di Jakarta. 2) Pihak pembeli meminta agar produk tersebut dapat diantarkan ke area pintu masuk Monas dan dipasangkan tulisan "gratis" tanpa sepengetahuan dan perizinan dari pihak PT. Nippon Indosari Corpindo Tbk. Demikian informasi ini kami sampaikan agar tidak terjadi kesalahpahaman diberbagai pihak. PT. Nippon Indosari Corpindo Tbk. berkomitmen untuk selalu menjaga nasionalisme, keutuhan Negara Kesatuan Republik Indonesia (NKRI) dan Bhinneka Tunggal Ika, serta tidak terlibat dalam semua aktivitas kegiatan politik".

Pada awalnya, Sari Roti menuai pujian setelah foto pembagian roti gratis Sari Roti untuk peserta Aksi Super Damai 212 jadi viral. Akan tetapi, setelah diklarifikasi justru berbalik arah. Sebagian besar warganet yang mendukung Aksi Super Damai 212 justru mencemooh dan menghujat. Inilah yang menjadi pemicu boikot Sari Roti. Dengan demikian, terjadi blunder, pengumuman tersebut jusru menunjukkan bahwa penulis rilis tidak memahami masalah dan perpolitikan yang sedang terjadi di negeri ini. Rilis ini menuai banyak kecaman dari masyarakat.

Terlepas dari dampak yang dimunculkan dari pengumuman Sari Roti di atas, isi pengumuman itu berkaitan dengan strategi komunikasi yang mewadahi pilihan kata sebagai cerminan inti pesan yang diharapkan berdampak sesuai seperti yang dikehendaki oleh penyusun pesan. Jika merujuk pada pandangan Austin, maka terdapat beberapa hal yang berkaitan dengan isi pengumuman Sari Roti dalam sudut pandang filsafat bahasa biasa.

Menurut Austin, jenis ucapan bahasa tidak dapat ditentukan apakah benar atau salah. Dengan kata lain, ucapan performatif tidak bisa benar dan tidak bisa salah, akan tetapi bisa happy atau unhappy. Maksudnya pada tempatnya atau tidak ketika diucapkan, wajar atau tidak, dan bisa saja mengalamai kegagalan.

"We may, however, fortify ourselves in the conviction that the distinction is a final one by reverting to the old idea that the constative utterance is true or false and the performative is happy or unbappy”. (Austin, 1968:54). 
Nalar: Jurnal Peradaban dan Pemikiran Islam

Vol. 2, No. 2, Desember 2018

Berikut beberapa hal kegagalan komunikasi yang dimunculkan oleh pengumuman Sari Roti menurut sudut pandang Austin. Pertama, pada jenis ucapan baik konstatif maupun performatif. Ucapan konstatif adalah jenis ucapan bahasa yang melukiskan sesuatu apa adanya atau faktual, meskipun masih mempunyai konskuensi apakah ucapan itu dapat ditentukan benar atau salah. Hal ini dapat ditemukan pada bagian isi pengumuman Sari Roti berikut ini.

"Sehubungan dengan beredarnya informasi mengenai adanya pembagian produk Sari Roti secara gratis oleh penjual roti keliling (bawker tricycle) para aksi Super Damai 212."

Pernyataan di atas memang menggambarkan adanya suatu peristiwa, yakni aksi super damai 212, akan tetapi yang berkaitan dengan pembagian produk Sari Roti secara gratis masih samar karena hanya sebatas informasi yang beredar di masyarakat, baik disaksikan secara langsung, maupun dari informasi yang ramai di media sosial.

Sementara pada ucapan performatif, yakni ucapan bahasa yang tidak dapat ditentukan apakah benar atau salah, akan tetapi bisa happy atau unhappy, maksudnya pada tempatnya atau tidak ketika diucapkan, wajar atau tidak, dan bisa saja mengalamai kegagalan. Hal ini dapat dilihat dari ungkapan isi pengumuman sari Roti berikut ini.

"PT Nippon Indosari Corpindo Tbk senantiasa berkomitmen menjaga Nasionalisme, keutuhan Negara Kesatuan Republik Indonesia (NKRI) dan Bhineka Tunggal Ika dengan senantiasa berusaha untuk menjadi perusahaan kebanggaan Indonesia”.

Seperti apapun pernyataan itu diungkapkan, dengan struktur yang teratur, namun nampak terdapat tuduhan bahwa peserta aksi damai 212 seakan-akan tidak dapat menjaga 2 (dua) dari 4 (empat) pilar bangsa yaitu NKRI, Bhineka Tunggal Ika, Pancasila, dan UUD 45.

Kemunculan informasi mengenai pembagian produk Sari Roti secara gratis oleh penjual roti keliling (bawker tricycle), merupakan kejadian yang berada di luar kebijakan dan tanpa seizin PT Nippon Indosari Corpindo Tbk. Suka tidak suka, kata-kata di atas berdampak tidak hanya bagi si penutur, tetapi juga bagi yang mengetahui isi tuturan tersebut. Bagi Sari Roti, reaksi yang muncul tidak diprediksi sebelumnya, sedangkan warganet dan masyarakat kebanyakan berasa kecewa dengan pengumuman Sari Roti tersebut, dan ujung-ujungnya terjadi boikot besar-besaran terhadap Sari Roti. Implikasinya para penjual dan pelanggan Sari Roti, terutama dari kalangan umat Islam, khususnya lagi yang mengikuti Aksi Damai 212 banyak yang memutuskan untuk berhenti menjual dan tidak lagi berlangganan Sari Roti, dan mencari merek roti lain.

Akibat pengumuman yang viral itu, Sari Roti bukan hanya mengalami pemboikotan, tetapi juga kerugian finansial. Dampak tersebut sebagaimana diberitakan oleh Tempo (2017) bahwa harga saham pemilik merek dagang Sari Roti, PT Nippon Indosari Corpindo Tbk, turun cukup dalam. Saham ini turun menyusul klarifikasi Sari Roti yang membantah telah memberikan dukungan terhadap aksi damai 212. Berdasarkan pantauan di RTI Business, pada penutupan perdagangan sesi pertama harga saham Sari Roti terpantau turun 0,66 persen atau 10 poin ke level Rp 1.510 per lembar saham. Sebelumnya, saham Sari Roti dibuka flat dari penutupan kemarin di level Rp 1.520. Saham sempat turun di level terendah sebesar 1,31 persen atau 20 poin di harga Rp 1.500. Adapun harga saham mencapai level tertingginya di posisi Rp 1.525. Saham Sari Roti hingga sesi I perdagangan melibatkan transaksi 40,4 ribu lembar saham dengan nilai transaksi Rp 60,93 juta dan diperdagangkan sebanyak 93 kali.

Kedua, Tindakan Bahasa. Menurut Austin, filsafat bahasa biasa tidak hanya membatasi pada analisis arti berbagai macam bahasa biasa saja, tetapi juga menganalisis 
Nalar: Jurnal Peradaban dan Pemikiran Islam

Vol. 2, No. 2, Desember 2018

ungkapan atau ucapan yang berkaitan dengan tindakan si penutur bahasa. Dalam hal ini dibedakan menjadi 3 (tiga) macam.

Pertama, tindakan lokusi. Ucapan atau isi tuturan, akan berlanjut pada tindakan bahasa. Dengan kata lain, suatu ucapan atau pernyataan yang dilontarkan menggambarkan tindakan atau perbuatan yang akan dilakukan, termasuk tanggung jawab atau akibat yang ditimbulkan dari ucapan tersebut. Melihat pengumuman resmi Sari Roti, justru terkesan keberpihakan apalagi dengan statemen tidak terlibat kegiatan politik apapun. Padahal, dalam Aksi Super Damai 212 tak ada satu pun tokoh politik atau pun yang berafiliasi ke partai politik tertentu.

Kedua, tindakan illokusi. Pada tindakan ini, Austin lebih menekankan tindakan dalam mengatakan sesuatu daripada tindakan mengatakan sesuatu. Guna mengetahui sejauh mana daya yang termuat dalam tindakan ini dalam memainkan peranannya pada diri penutur, dapat dilihat isi pengumuman Sari Roti butir ke-2.

"PT Nippon Indosari Corpindo Tbk. senantiasa berkomitmen menjaga

Nasionalisme, keutuhan Negara Kesatuan Republik Indonesia (NKRI) dan

Bhinneka Tunggal Ika dengan senantiasa berusaha untuk menjadi perusahaan kebanggaan Indonesia"

Dengan pernyataan itu, justru pihak Sari Roti telah melakukan judgement Aksi Super Damai 212 adalah aksi politik, tidak sejalan dengan Nasionalisme, Keutuhan Negara, dan Bhineka Tunggal Ika.

Ketiga, tindakan perlokusi. Isi tuturan dalam tindakan perlokusi lebih mengena kepada pada diri si pendengar, dalam hal isi pengumuman sari roti, maka isi pengumuman lebih mengena kepada si pembaca. Dengan kata lain, ia berbicara mengenai pengaruh yang ditimbulkan oleh isi tuturan, baik nyata maupun tidak.

"Demikian informasi ini kami sampaikan agar tidak terjadi kesalahpahaman diberbagai pihak. PT Nippon Indosari Corpindo Tbk. berkomitmen untuk selalu menjaga Nasionalisme, keutuhan Negara Kesatuan Republik Indonesia (NKRI) dan Bhinneka Tunggal Ika, serta tidak terlibat dalam semua aktivitas kegiatan politik".

Setelah isi pengumuman ini beredar luas di masyarakat dan sempat viral, segera muncul ajakan dari warganet agar produk Sari Roti diboikot. Rupa-rupanya apa yang sudah dirancang dan diarahkan sedemikian rupa oleh perusahaan tidak berjalan lancar, malah sebaliknya.

Potongan kalimat lain dari pengumuman resmi Sari Roti yang menyakiti peserta Aksi Super Damai 212 yang menyebutkan bahwa PT Nippon Indosari Corpindo Tbk tidak terlibat dalam semua kegiatan politik. Kalimat ini turut dipersoalkan sebagai pijakan untuk mengklarifikasi ulah penjual roti keliling (bawker tricycle) yang membagikan makanan kepada peserta aksi 212. Pengumuman tersebut secara tidak langsung seolah menuduh aksi 212 itu bermuatan politik. Padahal dalam pandangan peserta, aksi itu murni perjuangan menegakkan keadilan untuk penuntasan kasus hukum penistaan agama yang dilakukan oleh Ahok sehingga tidak ada hubungan dengan aksi politis. Bukti tidak terlibat dalam politik tertentu, dapat dilihat tatkala Presiden Joko Widodo mengikuti gelaran salat Jumat bersama dalam Aksi Super Damai 212 di areal lapangan Monas Jakarta Pusat.

Sebelum pengumuman muncul, banyak orang bersimpati karena pembagian Sari Roti secara gratis itu dianggap dukungan terhadap aksi umat. Akan tetapi setelah muncul bantahan dari Sari Roti, tidak sampai 24 jam, ajakan untuk tidak membeli Sari Roti berembus ke mana-mana. Bahkan Sari Roti pun menghapus isi pengumuman tersebut dari laman resminya, tetapi terlambat, nasi sudah menjadi bubur, tidak dapat diapa-apakan lagi. 
Nalar: Jurnal Peradaban dan Pemikiran Islam

Vol. 2, No. 2, Desember 2018

\section{Kesimpulan}

Berdasarkan paparan di atas, maka dapat ditarik simpulan sebagai berikut: 1) Secara garis besar filsafat bahasa biasa John L.Austin meletakkan objek materialnya pada bahasa sehari-hari yang digunakan oleh manusia dalam kehidupannya dalam bentuk ucapan sekaligus sebagai suatu tindakan; 2) Pengumuman Sari Roti memenuhi syarat dan layak untuk dibedah menggunakan pisau analisis filsafat bahasa biasa John Langshaw Austin; 3) Dampak yang dimunculkan pengumuman Sari Roti dalam pandangan filsafat bahasa biasa John L. Austin adalah unhappy. Pengumuman itu memang sempat muncul hanya beberapa jam sebelum dihapus secara resmi oleh Sari Roti, akan tetapi menjadi sia-sia karena tidak memperhatikan situasi dan kondisi tempat suatu informasi itu ditampilkan. 
Nalar: Jurnal Peradaban dan Pemikiran Islam

Vol. 2, No. 2, Desember 2018

\section{DAFTAR PUSTAKA}

Austin, J.L. 1968. How to Do things with Words. New York: Oxford university Press.

Bakker, A. 1986. Metode-Metode Filsafat. Jakarta: Ghalia Indonesia.

Bertens, K. 2002. Filsafat Kontemporer Inggris-Jerman. Jakarta: Gramedia Pustaka Utama.

Djojosuroto, K. 2007. Filsafat bahasa. Yogyakarta: Pustaka Book Publisher.

Kaelan. 1998. Filsafat Bahasa Masalah dan Perkembangannya. Yogyakarta: Paradigma.

Kaelan. 2006. Perkembangan Filsafat Analitika Bahasa dan Pengaruhnya terhadap Ilmu Pengetahuan. Yogyakarta: Paradigma.

Mustansyir, R. 1995. Filsafat Analitik Sejarah Perkembangan dan Peranana Para Tokohnya. Jakarta: RajaGrapindo Persada.

Poedjawiyatna. 1990. Pembimbing ke Arah Filsafat. Jakarta: Rineka Cipta.

Priyatna, J. E. 2017. Ancaman represi digital. Kompas: 7. Diakses pada 4 Januari 2017.

Sudarto. 1996. Metodologi Penelitian Filsafat. Jakarta: Rajawali.

Tribunnews, Foto Mereknya Saat Aksi 212 Viral, Pihak Sari Roti Keluarkan Pernyataan Resmi, diakses Juli, 20, $2017 . \quad$ dari http://www.tribunnews.com/nasional/2016/12/06/foto-mereknya-saat-aksi-212viral-pihak-sari-roti-keluarkan-pernyataan-resmi?page $=2$.

Tempo, Saham Sari Roti Turun Dampak Bantahan Bagi Roti Gratis?, diakses Juli, 25, 2017, dari https://bisnis.tempo.co/read/826065/saham-sari-roti-turun-dampak-bantahanbagi-roti-gratis. 